\title{
ENGENHO DE COMPOSIÇÃO: A FORMAÇÃO DO PROFESSOR DE DANÇA NO CONTEXTO DA UNIVERSIDADE ESTADUAL DO SUDOESTE DA BAHIA- UESB
}

Silvana Ribas dos Santos ${ }^{1}$

\begin{abstract}
RESUMO: $O$ assunto discutido neste artigo é parte dos estudos desenvolvidos em minha pesquisa de mestrado, defendida em 2019, junto ao Programa de Pós-Graduação em Dança da Universidade Federal da Bahia, que propõe, analisar as contribuições do Programa de Extensão Engenho de Composição na formação dos discentes do Curso de Licenciatura em Dança da Universidade Estadual do Sudoeste da Bahia, avaliando as ações do mesmo como agente de formação dos futuros professores de Dança. No recorte ora apresentado, destaca-se o Engenho de Composição pelas possibilidades de formação, de construção de vínculos e compartilhamento artístico com a comunidade. Foram utilizadas neste trabalho: análise de documentos, a exemplo do Projeto Político Pedagógico do curso de Licenciatura em Dança, depoimentos de egressos do curso de Licenciatura em Dança e entrevistas semiestruturadas do tipo conversacional, tendo como informantes os professores que passaram pela coordenação do Programa de Extensão Engenho de Composição. A pesquisa possui abordagem metodológica qualitativa baseada em observação participante. Nas considerações finais, destaca-se a perspectiva emancipatória inerente ao fazer artístico e suas contribuições para o campo da dança.
\end{abstract}

Palavras- Chave: Extensão Universitária; Formação em Dança; Processos Criativos.

ABSTRACT: The subject approached on this article is part of studies developed in my master's research, defended in 2019, with the Postgraduate Program in Dance of the Federal University of Bahia, which proposes to analyze the contributions of the Extension Program Workshop of Composition in the training of students developed in my master's research, defended in 2019, with the Postgraduate Program in Dance of the Federal University of Bahia, which proposes to analyze the contributions of the Extension Workshop Program of Composition in the training of students of the Degree in Dance from the State University of Southwest Bahia, evaluating its actions as a training agent for future dance teachers. In the cut presented here, the Wit of Composition stands out for the possibilities of training, building bonds and artistic sharing with the community. The following were used in this work: analysis of documents, such as the Pedagogical Political Project of the Dance Degree course, testimonials from graduates of the Dance Degree course and semistructured conversational interviews, with informants the teachers who underwent the coordination of the Education Program Of Composition 'Engine' Extension. The research has a qualitative methodological approach based on participant observation. At last considerations, the emancipatory perspective inherent in artistic making and its contributions to the field of dance are highlighted.

Keywords: Dance training; University Extension; Creative Processes.

\section{Introdução}

A Licenciatura em Dança foi implantada em 2010 em Jequié, na Universidade Estadual do Sudoeste da Bahia (UESB). Este episódio constituiu um marco histórico na

\footnotetext{
${ }^{1}$ Mestre em Dança e Especialista em Estudos Contemporâneos em Dança pelo Programa de Pós Graduação em Dança da Universidade Federal da Bahia (UFBA). Licenciada em Dança pela Universidade Estadual do Sudoeste da Bahia (UESB).Contato: vana_ribas@hotmail.com.
} 
cidade: pioneiro do interior do estado, traz consigo uma revolução artístico/educacional na região sudoeste da Bahia. Mesmo ainda em fase de consolidação, a graduação vem assumindo certa abrangência social na cidade, contribuindo para a formação de futuros professores de dança e estabelecendo relações artísticos/culturais na cidade.

O curso que inaugurou sua existência com a nomenclatura de Licenciatura em Artes com Formação em Dança ou Teatro foi implantado na UESB, em resposta às demandas que foram surgindo na época. Os professores da área de Teatro e Dança solicitaram ao Departamento de Ciências Humanas e Letras (DCHL) uma comissão que promovesse uma reforma curricular, resultando na proposta de desmembramento do curso de Licenciatura em Artes com Formação em Dança e Teatro, em dois cursos de linguagens específicas: Licenciatura em Dança e Licenciatura em Teatro, informação essa que consta em textos legais como o Projeto Político Pedagógico (PPP) do curso de Licenciatura em Dança, por exemplo.

Segundo o PPP do curso de Licenciatura em Dança, a reformulação visava uma ampliação do sentido de formação de educadores de Teatro e Dança, advindo de múltiplas necessidades, como a de propiciar uma experiência artística mais consistente para os estudantes em formação, uma vez que o currículo antigo era carregado de disciplinas teóricas e lacunas no que diz respeito à prática artística. Na justificativa do documento em questão alguns dos objetivos para o desmembramento se atém a: "1. Melhorar a qualidade do ensino; 2. Minorar possíveis lacunas teóricas, estéticas, políticas e poéticas nas quais o projeto original parecia incorrer" (UESB, 2011, p. 4).

Os cursos de Dança e Teatro foram viabilizados em Jequié a partir do interesse do Departamento de Ciências Humanas e Letras em integrá-los. O primeiro currículo concretizou-se: "Foi em função do movimento do Professor Jorge Barros (Matemática UESB), Eduardo Tudella (Teatro - UFBA) e Suzana Martins (Dança - UFBA) (SCHETTINI, 2013, p. 120)" que elaboraram a matriz curricular e deflagraram as contribuições necessárias para a implantação dos cursos.

O Engenho de Composição, foi implementado logo após o ano de criação dos referidos cursos (2010). Criado pelo professor Roberto de Abreu (in memoriam)2, é um programa continuado de extensão para difusão das produções cênicas dos cursos de Licenciatura em Dança e Teatro. Ou seja, é a partir desta ação que os discentes apresentam seus espetáculos no final de cada semestre, resultados das disciplinas experenciadas nos cursos, que são oferecidas do $1^{\circ}$ ao $4^{\circ}$ semestre. Essa iniciativa contribui para a experiência artística na formação de professores e, simultaneamente promove a formação de espectadores.

\footnotetext{
2 Dramaturgo, encenador, ator, performer e professor de Teatro. Doutor em Artes Cênicas pelo PPGAC / UFBA. Professor dos cursos de Licenciatura em Dança e Licenciatura em Teatro - UESB. Foi o primeiro professor com formação na área, com grande contribuição para o crescimento dos referidos cursos.
} 
O programa Engenho de Composição testemunha uma experiência artística e política permeado por estudos, investigação e produção. A força desses encontros faz desabrochar produções artísticas e daí nasce um engajamento político, que faz consolidar a existência do curso de Licenciatura em Dança no interior da Bahia. O curso cresceu, se desdobrando através da extensão, colaborando com os modos de ser e estar na comunidade.

\section{A experiência artística na formação do professor de Dança}

A formação do artista consiste em uma experiência inacabada, composta de ciclos que se fecham, dando abertura para outros se iniciarem, a cada experiência no palco, na rua, ou em grupo vai se estabelecendo uma relação de aprendizado e o artista vai criando intimidade com o seu fazer. Nessa perspectiva, a familiaridade com os elementos que são inerentes para a atuação profissional de um artista no campo da dança, requer aproximação minuciosa para o exercício na esfera do sensível.

Repousa sobre essa questão a premissa de pensar a formação em Dança, praticando dança, não apenas discutindo, insistindo na formação do professor de dança associada à experiência artística. A vivência artística é necessária durante a etapa da graduação, desperta no discente aprendizados e entendimentos sobre e como fazer dança em diversos contextos, seja na escola, no palco italiano, na rua ou em outros segmentos. Diante disso, incidem algumas provocações. É possível formar o professor de dança sem que o mesmo passe pela experiência artística?

Se tal questionamento sustentar a resposta sim, como o mesmo vai ensinar em espaços como escolas, academias de dança ou ser coreógrafo de uma companhia se esses saberes não passaram pelo seu corpo? Como desenvolver tal trabalho, se não existe uma intimidade com os elementos que constituem a cena, como figurino, maquiagem, cenário, entre outros, para desenvolver uma mostra artística em um festival na escola, - espaço mais comum onde irão atuar como licenciados -, por exemplo?

Nesse sentido, o Programa de Extensão Engenho de Composição é analisado como um espaço que possibilita que os discentes do curso de Licenciatura em Dança tenham a experiência da prática artística, dessa forma, o objetivo da pesquisa consistiu em compreender quais os caminhos existentes no programa que levam para a formação artística.

Não existe uma definição para tal tema, - formação artística -, entre as linhas de pesquisa que se dedicam a estudar sobre o assunto, porém têm se destacado as discussões que perpassam a reflexão do professor no âmbito das Artes, em especial, porque outros tantos autores em seus fluxos de pesquisa têm se debruçado sobre a experiência artística no ensino superior, tais como: Loponte (2005), Strazzacappa e Morandi (2006), Almeida (2009) e Molina (2015).

Loponte (2005) debate em sua pesquisa de doutorado denominada DocênciaArtista: Arte, Estética de Si e Subjetividades Femininas, sobre as suas próprias experiências 
e do grupo de pesquisa do qual faz parte; fala das práticas pedagógicas de artistasdocentes, identificando uma precariedade na formação em Arte, evidenciando os possíveis caminhos para a construção de uma docência-artista, sendo esse termo utilizado para sinalizar a aproximação entre ser professor e ser artista, como algo que não é separado, acontece simultaneamente.

Strazzacappa e Morandi (2006) têm efetivado contribuições acerca dessa temática, são autoras que, majoritariamente, estudam a indissociação do fazer artístico como parte integrante da formação dos professores de dança, evidenciando em suas publicações o que é indispensável na formação de um artista-docente a experiência de/no palco. O livro das autoras intitulado Entre a Arte e a Docência: A Formação do Artista da Dança é um exemplo de produção tratando deste assunto.

Almeida (2009) é uma pesquisadora que também estuda essa temática, adota a expressão artista-professor para discutir a prática do ensino artístico, buscando compreender como se faz e ensina arte nos cursos de ensino superior. A autora analisou de que forma se dá o ensino de arte através de 27 entrevistas concedidas por artistas/professores atuantes na universidade, investigando a prática cotidiana de cada um e deste modo afirma sobre as possíveis relações entre a produção artística e o ensino de arte. Essa discussão é apresentada no livro Ser Artista, ser professor: razões e paixões do ofício.

Sobre a experiência artística, Molina (2015) em sua tese de doutorado em Artes Cênicas intitulada Experiência Artística no Ensino Superior em Dança: Ativações para um Currículo Encarnado, se debruça sobre essa problemática, discute sobre a importância de um currículo que incorpore saberes da prática artística na graduação em dança, estabelecendo um panorama sobre sua formação artística consolidada no âmbito acadêmico. Dessa maneira, o autor afirma:

\footnotetext{
Minha trajetória na dança tem a experiência artística como grande espaço de formação e, dentro desse escopo, é possível elencar situações como os estudos de técnicas e de composição em dança, pesquisas sobre o corpo e sobre a história das artes e da dança, vivências de palco, criação colaborativa, participação em festivais e mostras, circulação de trabalhos artísticos, dentre outras. A universidade tangencia minha prática artística com a sistematização dessa experiência e com a reflexão crítica sobre minha produção (MOLINA, 2015, p. 90 ).
}

Como visto, existe uma diversidade de abordagens que trazem contribuições para esse debate. Nota-se também que expressões como docente-artista, artista-docente, artista-professor, são reflexo de estudos que buscam compreender o modo como a formação em arte é realizada nas universidades, demonstrando o sentido amplo de formação. Neste trabalho, a formação artística é compreendida como experiência inacabada, buscando entender de que forma o espaço onde os discentes compartilham vivências de estudos e pesquisa contribuem para a formação dos mesmos. 
A formação artística como experiência inacabada reside em movimentar os ciclos das vivências transformando-as em aprendizagem, esses ciclos se renovam na medida em que a prática vai estruturando os saberes do sujeito em torno de estudos sobre o corpo, a cena, o espaço, o tempo, dentre outros quesitos inerentes ao exercício artístico. Assim, a formação artística nunca se fecha ou finda através de um produto pronto e acabado, mas tem abertura para agregar novas experiências e novos significados que vão entrelaçandose, para germinar em aprendizado.

Deste modo, compreendo o Engenho de Composição enquanto um ambiente potente para promoção da formação artística. Atrelada ao inacabamento, alguns aspectos podem caracterizar essa ideia: a) O aprendizado não se finda nos espetáculos apresentados nesse espaço, se estende nos estágios de prática artística-pedagógica através de um projeto desenvolvido pelos discentes em espaços de aprendizado ou na educação básica, dando ao discente autonomia de pensar a concepção da coreografia, dos processos criativos, da performance e entre outros, além de desenvolver habilidades específicas para ordenar seus trabalhos individuais; b) Essa experiência se desdobra também, através da circulação de apresentação desses espetáculos em outras cidades através de editais de fomento à cultura. Pode acontecer interesse por parte do professor que dirigiu o espetáculo, em comum acordo com os discentes, de levar a produção adiante, ao circular em outras cidades, outros palcos, tendo nesses contextos ativado um modo de aprender singular. A respeito desses dois tópicos percebe-se o aprendizado contínuo, que perpassa os espaços de um extremo ao outro, da universidade à escola, do palco à rua.

\section{Engenho de Composição: configuração e circuito de articulações artísticas}

O Engenho de Composição implementado logo após o ano de criação do curso de Licenciatura em Dança foi criado pelo professor Roberto Ives de Abreu Schettini (in memoriam). É um programa continuado de extensão, que, ao final de cada semestre reúne os resultados cênicos das disciplinas de natureza prática do curso de Dança, recebendo as produções cênicas que integram os estudantes do Curso de Licenciatura em Dança e Licenciatura em Teatro da UESB.

A proposta do Engenho de Composição consiste em oferecer espetáculos gratuitamente para o público, contribuindo para a experiência artística na formação dos discentes e, simultaneamente promovendo a formação de espectadores. A realização é semestral, durante três dias na semana, ocupando espaços culturais disponíveis na cidade.

Assim, pensando o contexto artístico da cidade de Jequié, que não proporciona que o discente transite em outros lugares, como grupos, coletivos, workshops, apenas em escolas de ballet; as outras atividades como mostra de dança, mostra de teatro, oficinas, festivais de dança e manifestações da cultura popular acontecem com pouca frequência ou simplesmente não acontecem. Nesse sentido, essa realidade de acesso a outros lugares 
que conduzem os trajetos da formação em dança não ocorrem, sendo realidade, geralmente, apenas nas grandes capitais.

Assim, o programa de extensão acaba sendo o espaço mais acessível para que os discentes possam experimentar a prática artística, constituindo-se como um ambiente que auxilia na formação artística, onde os estudantes além de se apresentarem, possam apreciar espetáculos de dança ou teatro semestralmente, acessando outras intervenções artísticas, caracterizando-se em um exercício fundamental para o artista: apreciar a produção de outros artistas.

O mesmo é composto de duas ações entrelaçadas, que caminham juntas: a primeira, com ênfase na criação, consiste da vinculação entre os espetáculos apresentados e os processos criativos realizados nas disciplinas dos cursos de Licenciatura em Dança e Teatro; a segunda, com ênfase na difusão, diz respeito a apresentação dos espetáculos e sua relação com a comunidade.

Essa última ação intitulada como Mostra Cênica e Didática reúne outras atividades que foram criadas no intuito de fortalecer o diálogo entre a comunidade do território e a Universidade: (1) Seminários de Criação; (2) Interfaces Poéticas e (3) Diálogos da Cena.

Os Seminários de Criação são caracterizados pelo compartilhamento e discussão dos processos criativos com o público, com foco no debate das especificidades de cada um e sua relevância no campo da produção artística. Esta ação é realizada aproximadamente um mês antes da Mostra Cênica e Didática, já se conformando como um momento de sensibilização e mobilização de espectadores. Nessa oportunidade o público conhece o processo de montagem de cada espetáculo: o tema gerador; as escolhas estéticas; as técnicas de dança; os distintos procedimentos de criação. Essa ocasião ainda conta com a discussão das teorias que guiam os processos criativos e os estudantes e seus orientadores ampliam o debate, revelando as pesquisas enquanto um elemento intrínseco ao espetáculo.

Interfaces Poéticas, criado pelo Prof. Ms. Aroldo Fernandes 3 , tem o objetivo de trazer apresentações artísticas como resultado prático das disciplinas, incide numa atividade de curta duração, por exemplo, exposições, instalações, leitura de textos dramáticos, apresentação de banners, realizada pelos estudantes do curso de Dança e Teatro. Demais artistas da comunidade de Jequié também podem propor os seus trabalhos durante essa ação.

\footnotetext{
${ }^{3}$ Mestre em Artes Cênicas pelo Programa de Pós-Graduação em Artes Cênicas PPGAC/UFBA. Pesquisa Teorias da Performance, questões de gênero e sexualidade, dança e tecnologia e cultura visual. Possui Bacharelado no curso de Dançarino Profissional e Licenciatura em Dança pela Universidade Federal de Bahia. Atualmente é professor da Universidade Estadual do Sudoeste da Bahia, no Departamento de Ciências Humanas e Letras onde ministra para o curso de Licenciatura em Dança disciplinas relacionadas com a criação coreográfica e técnicas corporais.
} 
O projeto Interfaces Poéticas acontece paralelamente aos espetáculos, realizado no intervalo dos mesmos, na maioria das vezes ocupa espaços como foyer e galeria de artes do teatro, priorizando a diversidade de linguagens artísticas. O deslocamento do público entre as apresentações mostra ao mesmo a prática artística como resultado de estudos e pesquisas.

Finalmente, o Diálogos da Cena constitui um espaço de discussão e reflexão, que acontece após a Mostra Cênica e Didática, docentes e discentes da universidade são convidados para debaterem e fazerem uma análise crítica dos espetáculos apresentados, como também, avaliar a edição do programa, pontuando o que foi produtivo e as fragilidades. Neste encontro, os discentes convidados ladeados pelos professores, problematizam questões sobre os espetáculos, falando sobre as suas impressões e fruição.

Como qualquer circuito artístico tem suas ações para existir, os discentes estreitam laços com as demandas de produção dos espetáculos, se conectando com os bastidores da lida diária de artistas que fazem a produção dos seus próprios trabalhos. Nesse viés, forma-se uma equipe que se responsabiliza pela divulgação dos espetáculos, pela busca apoio; outros buscam a pauta de teatros, discentes ocupam as bilheterias do teatro, outros se direcionam para recepção do teatro encaminhando o público para a sala principal ou para as mostras artísticas do interfaces poéticas, como explicam os coordenadores entrevistados. Vejamos o que nos relata o coordenador da edição 2016.1:

[...] no que diz respeito a estrutura de conseguir colocar de pé o Engenho, eu trouxe um amigo de Salvador para fazer uma oficina de produção executiva pros estudantes, teve uma ação de formação, veio esse profissional para organizar esses estudantes colaboradores, foram 11, fizeram oficinas, para poder ativar a parte estrututral e logística do programa, pessoas que ficaram responsáveis com a divulgação, com a parte de escritório: enviar memorando, ofícios a setores, a entidades como prefeitura, centro de cultura, conseguir pauta, conversar com o pessoal de assessoria de imprensa, marcar entrevista em rádios, então, foi uma oficina pensada para a execução do programa, entendo como pré-produção, produção e pós-produção [...].

Tais envolvimentos colocam os discentes num lugar onde os mesmos possam pensar sobre os acontecimentos por trás da cortina, refletindo sobre as reverberações do trabalho em grupo. Essa experiência artística cravada numa relação entre discentes, docentes e comunidade, necessita entender o fazer artístico onde estudos distintos vigoram, logo, o objetivo do curso de Licenciatura em Dança, segundo o Projeto Político Pedagógico, é:

A missão do curso (...) é formar artistas/educadores/pesquisadores sensíveis às demandas contemporâneas, aptos a estabelecer bases para a comunicação entre o ser humano e sociedade através da dança; formar sujeitos preparados para intervir, produzir, apreciar, investigar e articular as diferentes linguagens artísticas com a dança, o contexto cultural e a educação (UESB, 2011, p. 44).

Essa é a configuração do Engenho de Composição que se encontra na sua XVI edição. Esse conjunto de proposições mostra a importância do princípio de aprendizagem na extensão universitária. O eixo da extensão no curso de Licenciatura em Dança está 
vinculado às atividades complementares, portanto, nessa direção, prevê a manutenção de atividades de extensão associadas às disciplinas de criação, articulando os conhecimentos teóricos-práticos apreendidos ao longo do curso. Essas atividades supõem um percurso de aprendizagem, delineando um trajeto mais compreensivo, ligado mais à experiência/sentido do que informativo, onde as informações são impostas e os estudantes não vivenciam os conhecimentos.

A Extensão permite a vivência de conteúdos em dança cultivando a relação téoricaprática, podendo ser vista como o campo de aplicação prática, pois na maioria das vezes simula o mercado de trabalho ao se relacionar com os produtos artísticos desenvolvidos pelos artistas-docentes em formação, qualificando a aprendizagem curricular.

\section{A Extensão como espaço de Aprendizagem}

Considerando a extensão universitária como ampliação do espaço de aprendizagem na formação docente, a mesma é definida no Plano Nacional de Extensão Universitária como "um processo interdisciplinar, educativo, cultural, científico e político que promove a interação transformadora entre Universidade e outros setores da sociedade" (FORPROEX, 2012, p. 16).

As atividades de extensão são de diferentes naturezas, portanto esse estudo presume a extensão artística como um processo que tem lógica própria para acontecer, se aproximando com os modos de fazer de um festival de artes cênicas, especificamente, no contexto dos cursos de Licenciatura em Dança e Teatro da UESB. Tendo em vista que uma extensão artística abrange muitas expressões de arte e são propostas com prioridades estéticas, poéticas e criativas, tais prerrogativas, servem de escopo para que esse espaço se configure enquanto lugar de formação artística.

Compreender o Programa de Extensão Engenho de Composição como laboratório de prática, implica pensar como a experiência foi ou está sendo construída no processo de formação dos graduandos. As disciplinas mencionadas a seguir são responsáveis pelos processos criativos que resultam em espetáculos que são levados para o programa, tais como:

- No primeiro semestre é oferecida a disciplina de Processos de Criação I: Teatro e Contemporaneidade. Nesta disciplina os alunos de ambos os cursos passam pela experiência de participarem da montagem de um espetáculo de teatro. Existe na proposta dos currículos dos cursos de Dança e Teatro da UESB, as disciplinas de tronco comum, onde nos $1^{\circ}$ e $2^{\circ}$ semestres os estudantes de ambos os cursos fazem as mesmas disciplinas;

- No $2^{\circ}$ semestre a disciplina Processos de Criação Il: Dança e Contemporaneidade, os estudantes participam da montagem de um espetáculo de dança. A partir do $3^{\circ}$ semestre os discentes de ambos os cursos seguem produzindo na sua área específica;

- Ainda nos $3^{\circ}$ e $4^{\circ}$ semestres os discentes do curso participam de processos criativos e montagem de espetáculos de dança. Faz parte do $3^{\circ}$ semestre a disciplina 
Estágio de Criação em Dança I: Vanguardas Modernas e do $4^{\circ}$ semestre a disciplina Estágio de Criação em Dança Il: Dança e Contemporaneidade.

Assim, a proposta de apresentar espetáculos se encerra no $4^{\circ}$ semestre. Como a atividade extensionista está ligada às disciplinas, o objetivo é que todos os alunos participem, sendo essa experiência de suma importância para o entendimento do fazer artístico.

O contato com as disciplinas de diversas naturezas, desde as de cunho teórico ao prático, cursadas do $1^{\circ}$ semestre até $04^{\circ}$ semestre provocaram conhecimentos, de percepção estética e de experimentação para os graduandos do curso de Licenciatura em Dança.

Os processos artísticos em dança destacam-se pelo seu caráter de investigação, são marcados pela aquisição de novos aprendizados em relação ao corpo, novas concepções sobre o corpo são estudadas. Dessa forma, durante o semestre, através do processo colaborativo os professores e alunos escolhem o tema do espetáculo. Em paralelo à essas escolhas acontece o estudo de propostas de figurino, maquiagem, iluminação e cenário, os discentes estreitam laços com elementos da cena, fazem as suas escolhas, pensam coletivamente e assumem uma postura crítica enquanto dançarinos. Veja o que nos fala o artista, professor da UERJ, Ricardo Basbaum:

Ser artista - ou funcionar como tal, se quisermos - não é conseqüência apenas de vontade e perseverança, mas de uma sutil negociação com vistas à inserção num campo de debates e jogo cultural, ou numa certa comunidade. Há sempre em jogo a construção de uma alteridade, a ansiedade de produção de sentido, a mobilização do olhar do outro: o artista parece ser aquele que inventa cuidadosamente um centro de atração frente ao qual as coisas são reveladas em suas estruturas de formação e intensidades: se consideramos o campo da arte algo "importante" é justamente porque aí se constrói um debate imprescindível para a continuidade e atualização da vida (BASBAUM, 2008, p. 27).

Pensando sobre as estruturas de formação, o pesquisador em dança, professor da UESB, Thiago Assis (2015), traz uma reflexão no artigo intitulado Múltiplos Olhares: A Formação do Professor de Dança em Questão, em torno do curso de Licenciatura em Dança, no qual atua como docente nas disciplinas de estágio. Parafraseando Assis (2015) sinalizo que o formador precisa estar atento para promoção de diálogos que mobilizem novos entendimentos sobre corpo, arte, educação e a própria dança, auxiliando-o na árdua tarefa de fazer emergir novos paradigmas para o ensino da dança. Para o referido autor não se pode desconsiderar esses fatores:

[...] é preciso investir na formação de um professor que conheça bem saberes inerentes a dança, estando preparado para ensinar essa linguagem artística em suas diferentes dimensões, desde o desempenho técnico interpretativo, passando pela apreciação estética e pelos processos de criação. A formação de Professores de Dança não deve se ater unicamente a ensinar repertórios de dança, porém, sim, ampliar o entendimento desse licenciando acerca das infinitas 
possibilidades de fazer/pensar dança, estimulando-o a olhar para essa arte como uma linguagem. (ASSIS, 2015, p.4)

Uma formação pautada exclusivamente em ensinar repertórios de danças limita a capacidade criadora, seja qual for o repertório, das danças tradicionais, daquelas de Matrizes Africanas, repertórios de balé, de dança moderna, entre outras danças, aprender somente os movimentos e características dos estilos existentes veta o estudante de acessar outros caminhos, neste sentido, as possibilidades de fazer/pensar pode acontecer pela criação de movimentos não codificados, pela improvisação, ou pensar na mesclagem entre as técnicas de danças, ressignificando o movimento. Esses caminhos também sensibilizam os discentes para atuação em salas de aula e outros contextos profissionais.

A dança limitada à reprodução de repertórios, como os repertórios de balé clássico, por exemplo, exige um corpo específico e qualidade técnica, entretanto, seria contraditório uma formação enviesada nesses pilares, pois ao adentrar as escolas o professor de dança lida com a diversidade de corpos.

Analisando as ementas das disciplinas de criação no currículo constatei estudos acerca do corpo nos processos criativos, a fim de permitir novos entendimentos. No quadro abaixo segue a ementa da disciplina Estágio de Criação em Dança I: Vanguardas Modernas, onde podemos visualizar tal ideia:

Quadro 1 - Ementa da disciplina Estágio de Criação em Dança I: Vanguardas Modernas.

\begin{tabular}{|l|c|c|}
\hline \multicolumn{1}{|c|}{ DCHL } & \multicolumn{1}{|c|}{ Carga Horária: 105h } & Créditos: (2.1.1) \\
\hline $\begin{array}{l}\text { Estágio investigativo prático-teórico sobre a criação artística e seus processos na Dança, voltados à } \\
\text { discussão das vanguardas modernas na dança e seus entendimentos sobre o Corpo. A utilização de mostras } \\
\text { coreográficas, dinâmicas de grupo, oficinas de composição coreográfica e leituras comentadas de textos } \\
\text { pertinentes à dança são alguns dos métodos propiciadores das atividades de ensino-aprendizagem desta } \\
\text { disciplina. }\end{array}$ \\
\end{tabular}

Fonte: Projeto Político Pedagógico/Dança - UESB, 2011.

Esse estágio permite pensar o contexto das Vanguardas Modernas e suas implicações no corpo e na dança, referências como, Isadora Duncan, Martha Graham e Rudolf Laban constam como bibliografia básica desta disciplina. Dessa maneira, a complexidade dos processos criativos não se limita ao que a ementa propõe. No lugar de discente que atravessou as disciplinas de estágios, percebi que a maioria dos professores amplificam os entendimentos sobre o corpo fazendo entrecruzamentos com a contemporaneidade. 
Pensando como a experiência é construída nos processos criativos, talvez os métodos utilizados, - mostras coreográficas, oficinas de composição coreográfica e leituras comentadas de textos -, fortalecem o debate sobre o artista enquanto investigador da própria experiência. Essa experiência vivenciada ao longo do processo de criação qualifica o fazer, exige do dançarino investigar o seu modo de fazer, de criar, de construir.

Além do mais, Jorge Larrosa em seu livro Tremores: escritos sobre experiência, vem discutindo e agregando outras definições à palavra experiência, problematizando a experiência/sentido, transportando-a para um lugar de ocorrências, um lugar do imprevisível, um lugar onde tudo pode acontecer e tal fator atravessa o sujeito, estruturando-o como experiência. $O$ autor tem o cuidado de apresentar precauções para falar sobre a experiência como fluidez, que move, que nada tem a ver com certezas e métodos para se chegar a algum lugar. Sobre isso, ele afirma:

A primeira precaução consiste em separar claramente experiência de experimento, em descontaminar a palavra experiência de suas conotações empíricas e experimentais. Trata-se de não fazer da experiência uma coisa, de não objetivá-la, não coisificá-la, não homogeneizá-la, não calculá-la, não torná-la previsível, não fabricá-la, não pretender pensá-la cientificamente ou produzi-la tecnicamente (LARROSA, 2014, p. 49).

A reconfiguração do conceito de experiência/sentido desperta a compreensão do programa Engenho de Composição como construção de relações, engendradas pelo espaço-tempo, ao lidar com o sensível, com a transgressão, com formas de fazer não lineares, com o imprevisível. A experiência que vigora nesse ambiente "tem relação com a subjetividade, a provisoriedade e a incerteza" (MOLINA, 2015).

Assim, os espetáculos produzidos nas disciplinas de criação deflagram uma série de saberes, sobre a cena, sobre os conteúdos de dança, sobre a relação dos dançarinos com a plateia, sobre a relevância do tema do espetáculo para a sociedade. Dessa forma, entende-se que dos processos criativos até chegar no programa de extensão são despertadas experiências de várias faces.

As demandas da extensão atreladas ao ensino criam frestas potentes, insurgindo num cenário inconstante com caráter multifacetado. Seria a extensão universitária no contexto do curso de Licenciatura em Dança um caminho para exercitar as múltiplas experiências que a conjuntura da cidade de Jequié oferece para desenvolver estudos e pesquisas em dança?

Existem rastros dessas experiências por meio do processo criativo do espetáculo intitulado Urbanus dirigido pela professora Ms. Vânia Oliveira ${ }^{4}$, nesse trabalho houve um

\footnotetext{
4 Licenciada, Especialista e Mestra em Dança pela Escola de Dança da Universidade Federal da Bahia. Especialista em História Social e Cultura Afro brasileira pela UNIME. Pesquisadora do Núcleo de Processos Educacionais em Dança - NUPED, que integra o GESTAR - grupo de estudos em territorialidades da infância
} 
estudo a partir das observações nas ruas de Jequié, realização de performances em lugares não convencionais, como a feira popular, no intuito de trazer as referências dos lugares observados. Serviu também para potencializar a investigação de movimentos.

\begin{abstract}
Portanto, é possível compreender que o tempo formal aprendente ocorre dentro de uma matriz curricular ou num período determinado para o desenvolvimento de uma pesquisa. A universidade, por meio da extensão, pode ressignificar o tempo linear ou o cíclico e proporcionar momentos alternativos de aprendizagem, participando de projetos de pesquisa e de extensão, inserindo-se em estágios ou iniciativas de voluntariado, compartilhando ações comunitárias ou serviços sociais. Essas iniciativas, geralmente, trasbordam a estrutura cronológica e possibilitam tempos alternativos de aprendizagem (SÍVERIS, 2013, p. 29).
\end{abstract}

Vale ressaltar que no ano de 2013 , esse espetáculo foi premiado na $3^{\text {a }}$ edição do AbriU Dança $a^{5}$ na categoria "Espetáculo Adulto" e a discente Maéli de Marcos foi contemplada na categoria “Bailarina Revelação". Compreendo a participação em eventos dessa natureza como fatores enriquecedores para o aprendizado dos discentes, os festivais se caracterizam também como espaço de aprendizagem, nessa conjuntura, alguns espetáculos, além do supracitado, que estrearam no programa participaram de vários festivais.

Paulatinamente, os profissionais de dança descobrem a importância da divulgação do saber construído em sua prática, não apenas ao apresentar as criações artísticas, mas ao aprender a discutir sobre elas. Os festivais de dança, além de servirem como mostra de coreografias, oferecem cursos (de fato, mais práticos que teóricos), palestras, debates, mesas-redondas, contribuindo com uma formação diferenciada do artista da dança. Enfatizo a importância da participação desses profissionais não apenas em festivais, mas em congressos, encontros, seminários e demais eventos, tanto artísticos quanto científicos (STRAZZACAPPA; MORANDI, 2006, p. $61)$.

Partindo desse viés, implica aos profissionais da dança não apenas apresentar a criação artística, mas aprender discutir diferentes aspectos sobre elas, nos diversos espaços nos quais perpassam. Vale ressaltar, a metodologia utilizada nos processos criativos da professora Vânia Oliveira. A mesma destaca através de depoimento que a aula de campo faz parte dos processos de ensino-aprendizagem que se propõe a fazer, pois, entende que dança pode produzir conhecimento a partir do corpo e de todos os contextos.

\footnotetext{
e formação docente, da UESB. Professora Assistente em dedicação exclusiva do curso de Licenciatura em Dança da UESB.

5 O AbriU Dança na Bahia propõe diálogos e conexões na diversidade da dança baiana. A ideia é abrir novas possibilidades de intercâmbio e fusão com profissionais da dança com diferentes experiências artísticas, ampliando o conhecimento do horizonte artístico e sociocultural, promovendo também provocações e contribuições profissionais para os artistas e outros que são conectados com a área. Um dos únicos projetos no seu perfil no estado, entrecruzando saberes, fazeres culturais em dança, tecendo redes nessa linguagem no seu território de realização. Tendo como principais ações: oficinas de dança, diálogos temáticos, cinedança e mostras coreográficas.

Disponível em: <https://abriudancanabahia.wordpress.com/o-abriu-danca-na-bahia/>. Acesso em: 28 set. 2018.
} 
Em conversa afirmou que por meio da transversalidade e interseccionalidade é possível ampliar o processo de ensino-aprendizagem.

A abrangência significativa dos espaços de aprendizagem aponta os entremeios que regem a formação artística:

(1) Múltiplos contextos enquanto produtores de saberes;

(2) Utilização de outra temporalidade em relação aquela imposta pelo currículo formal;

(3) A instabilidade de recursos para investimento em atividades formativas;

(4) Entendimento da formação do professor de dança como processo inacabado.

Diante dessa reflexão, é importante ponderar sobre os conhecimentos do campo da dança atrelados ao corpo, assim, valendo-se dessa ideia, a dança enquanto área do conhecimento vem organizando uma literatura pautada no corpo, na arte e na educação, só para citar alguns exemplos, pois sabe-se da amplitude e possibilidades dessa área.

Um programa artístico interdisciplinar dentro de uma universidade pública é uma ação que colabora para a emancipação dos docentes, discentes e comunidade. Assim, percebi que a extensão precisa ser fortalecida na comunidade, no sentido de oferecer oficinas ou outras atividades, onde a comunidade participe efetivamente. A criação de outras estratégias para se aproximar do público é um ponto que pode ser ampliado.

\section{Considerações Finais}

Ao falar de formação artística em dança como experiência inacabada a partir da extensão universitária, acende-se outros entendimentos sobre o exercício da formação em dança, sendo um exercício complexo, entendendo que cada universidade adota um modo de lidar com as etapas de formação. Nesta estudo fui instigada a promover uma discussão sobre formação artística, formulando ideias sobre o assunto e desenvolvendo os meus próprios conceitos. A experiência artística como processo de aprendizagem no contexto do Programa de Extensão Engenho de Composição, trouxe desdobramentos relevantes para a pesquisa.

O Engenho de Composição desde a sua criação em 2011 até a última mostra artística em 2018 conta com aproximadamente 44 espetáculos realizados, entre produções de Teatro e Dança. O mesmo é definido nesta discussão como espaço de formação artística, ao mesmo tempo que dinamiza a cultura da cidade de Jequié, colaborando para a formação de público e estimulando a criação do ambiente de produção.

Na lógica do Engenho de Composição a configuração propicia um alinhamento com os processos criativos realizados nas disciplinas de criação; é na prática que o discente entende sobre a relação com a plateia, com o espaço da apresentação: teatro, rua, foyer, praça, dentre outros espaços não convencionais. O foco desse estudo é baseado na extensão, um espaço de ocorrências das vivências artísticas, é uma maneira pela qual as 
produções artísticas chegam na comunidade, deste modo, é de inteira importância pontuar sobre esse eixo, ressaltando as diferenças no modo de atuação e o caráter político enviesado nesta vertente.

Diversos pesquisadores se debruçaram sobre a criação artística dentro de um lastro que contempla a diversidade dos sujeitos, através dos seus projetos de pesquisa ou projetos de extensão, ou até mesmo reinventado as metodologias e didáticas utilizadas em sala de aula, compreendendo que a inserção de outros modos de saberes também influem para a construção do conhecimento na academia. Essa perspectiva atinge os saberes contidos nas danças populares, nas danças de matrizes africanas, e nos repertórios da arte indígena, dentre outras correntes que operam nessas vertentes.

As questões aqui levantadas induzem a concluir que a experiência artística incorpora saberes necessários para a formação de discentes na Licenciatura em Dança. A análise da formação artística como fazer inacabado promove inquietações, já que esse fazer não se conclui na certeza e, sim na incerteza, permanecendo em construção nas práticas artísticas/educativas. Esse fazer que implica o corpo, contribui para o campo da dança, pois a organização de distintos pensamentos sobre os processos formativos alimenta a área.

\section{Referências}

ALMEIDA, C. M. C. Ser artista, ser professor: razões e paixões do ofício. São Paulo/SP: Editora UNESP, 2009.

ASSIS, T. S. Múltiplos Olhares: A Formação do Professor de Dança em Questão. In: Colóquio Internacional Educação e Contemporaneidade - EDUCON, v. 9, n. 01. Anais do Colóquio Internacional Educação e Contemporaneidade - EDUCON, São Cristóvão: set/2015, p. 1-9.

BASBAUM, R. Vivência crítica participante. ARS (São Paulo), v. 6, n .11, 2008.

FÓRUM DE PRÓ-REITORES DE EXTENSÃO DAS UNIVERSIDADES PÚBLICAS BRASILEIRAS FORPROEX. Política nacional de extensão universitária. In: Encontro Nacional de PróReitores de Extensão das Universidades Públicas Brasileiras. 2012, Manaus. Anais... Manaus/AM: FORPROEX, 2012.

Disponível em: <http://www.utfpr.edu.br/estrutura-universitaria/pro-reitorias/prorec/diretoria-de-extensao/documentos-da-extensaode-ambito nacional/politica-nacional-de-extensao-universitaria-forproex-2012/view>. Acesso em: 17 ago. 2018.

LARROSA, J. Tremores: escritos sobre experiência. São Paulo/SP: Autêntica, 2014.

LOPONTE, L. G. Docência Artista: arte, estética de si e subjetividades. 2005. 208 f. Tese (Doutorado em Educação) - Programa de Pós-Graduação em Educação, Universidade Federal do Rio Grande do Sul, Porto Alegre/RS, 2005.

MOLINA, A. J. Experiência artística no ensino superior em dança: ativações para um currículo encarnado. Tese (Doutorado em Artes Cênicas) - Programa de Pós-Graduação em Artes Cênicas, Universidade Federal da Bahia, Salvador/BA, 2015. 
- Revista de Iniciação à Docência, v. 5, n. 2, 2020 -

Publicação: agosto, 2020 - ISSN 2525-4332

SÍVERIS, L. O princípio da aprendizagem na extensão universitária. In: SíVERIS, L. (Org.). A extensão universitária como um princípio de aprendizagem. Brasília/DF: Liber Livro, 2013.

SCHETTINI, R. A. O Marujeiro da lua: Jogos performativos: política, poética e espetacularidade na formação de professores de teatro e de dança. 2013. 317 f. Tese (Doutorado em Artes Cênicas) - Escola de Teatro, Universidade Federal da Bahia, Salvador/BA, 2013.

STRAZZACAPPA, M.; MORANDI, C. Entre a arte e a docência: a formação do artista da dança. 1. ed. Campinas/SP: Papirus, 2006.

UNIVERSIDADE ESTADUAL DO SUDOESTE DA BAHIA. Projeto Político Pedagógico do Curso de Licenciatura em Dança. Jequié/BA, 2011.

. Projeto de Extensão Engenho de Composição. Jequié/BA: DCHL, 2018. 